\title{
Marine protected areas and migratory species: residency of green turtles at Palmyra Atoll, Central Pacific
}

\author{
Eugenia Naro-Maciel ${ }^{1, *}$, Felicity Arengo ${ }^{2}$, Peter Galante ${ }^{2}$, Erin Vintinner ${ }^{2}$, \\ Katherine E. Holmes ${ }^{3}$, George Balazs ${ }^{4}$, Eleanor J. Sterling ${ }^{2}$ \\ ${ }^{1}$ Liberal Studies, New York University, New York, NY 10003, USA \\ ${ }^{2}$ Center for Biodiversity and Conservation, American Museum of Natural History, New York, NY 10024, USA \\ ${ }^{3}$ Wildlife Conservation Society, Bronx, NY 10460, USA \\ ${ }^{4}$ Golden Honu Services of Oceania, Honolulu, HI 96825, USA
}

\begin{abstract}
Protected areas are a cornerstone of conservation strategies globally, yet questions remain about their impacts, including on highly migratory species. The Palmyra Atoll National Wildlife Refuge, one of the Northern Line Islands in the Central Pacific, contains a regionally significant green turtle Chelonia mydas foraging ground. Residency patterns of this species were investigated through satellite telemetry ( $\mathrm{n}=15$ males, 1 female, 2 subadults) and flipper tagging ( $n=555$ ) between 2008 and 2013. Almost every captured turtle was flipper-tagged, but telemetry efforts focused primarily on adult males, which have been studied infrequently. Overall, the turtles tracked during 4076 transmission days (mean $=227$, range $=37$ to 633 ) had high site fidelity and small home ranges, and remained close to their capture sites in waters $\leq 50 \mathrm{~m}$ deep. Five turtles were tracked for $>1 \mathrm{yr}$, but none left Palmyra on annual breeding migrations. Only one satellite-tracked turtle departed the atoll, covering a total distance of $\sim 5600 \mathrm{~km}$ in a near-circular loop. Similarly, flipper tag recaptures on the atoll $(n=67)$ occurred near the original capture site. However, additional tags were recovered from 1 female in Kiritimati, Northern Line Islands, and from 1 subadult in Kosrae, Micronesia, 690 and 3800 km away from Palmyra, respectively. Such extended, spatially restricted residency with low turnover is expected in small, high-quality habitats. The study highlights the importance of this protected area, which harbors regionally endangered turtles whose movements over several years are almost entirely encompassed within its established boundaries.
\end{abstract}

KEY WORDS: Marine protected area $\cdot$ Satellite tracking $\cdot$ Site fidelity $\cdot$ Home range $\cdot$ Hexagon grid $\cdot$ Kernel density $\cdot \mathrm{T}-\mathrm{LoCoH} \cdot$ Utilization distribution overlap index

\section{INTRODUCTION}

Marine protected areas (MPAs) are proving to be an important tool for countering threats such as habitat alteration, overexploitation, and climate change (Scott et al. 2012, Simard et al. 2016). The International Union for Conservation of Nature (IUCN, https://www.iucn.org/theme/protected-areas/about) defines a protected area as 'a clearly defined geo-

\footnotetext{
*Corresponding author: enmaciel@nyu.edu
}

graphical space, recognised, dedicated and managed, through legal or other effective means, to achieve the long-term conservation of nature with associated ecosystem services and cultural values'. However, reserves do not automatically achieve conservation outcomes. Globally, only $\sim 3.7 \%$ of the world's oceans are protected in actively managed MPAs, with as little as $\sim 2 \%$ considered to be strongly protected in no-take reserves (MCI 2018). Existing MPAs may fail to pro-

() The authors 2018. Open Access under Creative Commons by Attribution Licence. Use, distribution and reproduction are unrestricted. Authors and original publication must be credited. 
vide optimal habitat, and migratory megafauna, like marine turtles, benefit only partially from reserves due to limited protection measures or spatial coverage of their wide ranges, underscoring the importance of understanding a species' spatial ecology with respect to protected areas (McClellan \& Read 2009, Scott et al. 2012, Shimada et al. 2017).

The Palmyra Atoll National Wildlife Refuge (hereafter, 'Palmyra') is one of 7 reserves encompassed by the Pacific Remote Islands Marine National Monument (see Fig. 1). Palmyra is located within the Northern Line Islands, which span a gradient of human influence. The uninhabited US naval defense area of Kingman Reef lies to the north, and there are 3 increasingly populated islands of the Republic of Kiribati to the south (see Fig. 1). The remaining Central and Southern Line Islands are uninhabited. Access to Palmyra is currently restricted to research and management staff, but the atoll was occupied by the United States military during World War II. Significant structural changes were made then, such as connecting the islets and building an airstrip, although the reef flats were left largely intact (Papastamatiou et al. 2010). Palmyra was designated a US National Wildlife Refuge in 2001 and a Ramsar Wetland of International Importance in 2009. The atoll now contains relatively undisturbed coral reef and algal communities with robust marine turtle, shark, and manta ray populations (Braun et al. 2008, Sandin et al. 2008, Papastamatiou et al. 2010, 2012, Sterling et al. 2013, Williams et al. 2013, McFadden et al. 2014). Such small, high-quality habitats can be predictors of small home ranges, low turnover, and extended residency for many animals (Winker et al. 1995, Griffen \& Drake 2008).

Megafauna, including marine turtles, play key roles in maintaining ecosystem structure and function (Bjorndal \& Jackson 2003). Palmyra contains a regionally significant foraging ground for green turtles Chelonia mydas and Critically Endangered hawksbills Eretmochelys imbricata (Sterling et al. 2013). Green turtles are the dominant marine chelonian, and juveniles are the most frequent life stage encountered, with adult males and females each constituting about one-tenth of the population (Sterling et al. 2013). Palmyra's green turtles are generally very healthy (Sterling et al. 2013, McFadden et al. 2014). Further, none have yet been observed with fibropapillomatosis (Sterling et al. 2013, McFadden et al. 2014), a tumor-producing viral disease that has become common and often severe in some coastal foraging pastures such as those found in Hawai'i (Hargrove et al. 2016). Green turtles at Palmyra fall within the Central South Pacific Distinct Population Segment, a discrete grouping that was listed as endangered under the US Endangered Species Act in 2016 (NOAA, https://www.fpir.noaa.gov/PRD/prd_ green_sea_turtle.html). On a global scale, the IUCN also considers the species Endangered (Seminoff 2004). However, at Palmyra green turtles face few threats and forage in an environment free from pervasive human influence. Typical threats to marine turtles such as fishing and habitat alterations are currently prohibited there, and the human population is limited to refuge staff and researchers, although there is natural predation by sharks (Sterling et al. 2013). A beach suitable for nesting formed at Palmyra following habitat modification and sediment accumulation in the 1940 s but nesting is still rare (Maison et al. 2010, Sterling et al. 2013).

All marine turtles hatch from eggs on nesting beaches, where incubation temperature determines hatchling sex (Ackerman 1997). After a pelagic phase, green turtles generally recruit as juveniles to coastal foraging grounds, where they feed mostly on algae or seagrasses and smaller amounts of animal food items (Musick \& Limpus 1997, Russell et al. 2011). Adults undergo breeding migrations between often distant nesting and feeding habitats, although there are non-migratory groups (Godley et al. 2008, Whiting et al. 2008, Hart et al. 2013). Green turtles foraging throughout Hawai'i, for example, nest only within that archipelago and mainly at French Frigate Shoals, where females breed about every 4 yr (Balazs et al. 2015, 2017). Male marine turtles are less studied than the more accessible nesting females. In most marine turtle species, including green turtles, males are reported to reproduce more frequently than females, and some are capable of annual breeding (Wibbels et al. 1990, Limpus 1993, James et al. 2005, Van Dam et al. 2008, Hays et al. 2010, Wright et al. 2012, Nurzia Humburg \& Balazs 2014). Mating may occur offshore of, on the way to, or distant from the nesting beach (Limpus 1993, Plotkin 2003). Green turtles display natal homing behavior and often return to the rookery or region of their birth to breed (Meylan et al. 1990). Once reproductive activities are concluded, green turtles generally go back to their resident foraging grounds (Limpus et al. 1992, Limpus 1993, Plotkin 2003).

Foraging grounds are where turtles spend most of their lives and are more difficult to assess than nesting beaches. Mark-recapture, satellite tracking, and genetic research have revealed that foraging populations are usually 'mixed stocks' whose natal origins can be traced to multiple nesting beaches (Bowen \& 
Karl 2007). Green turtles foraging at Palmyra have been genetically traced to a mix of South-Central and West-Central Pacific Regional Management Units, an area which includes Micronesia (Naro-Maciel et al. 2014). As with other hard-shelled marine turtles, green turtle adult migrations and movements can be typified as targeted or direct, shuttling seasonally along coasts, pelagic living, or residing locally (Godley et al. 2008).

With respect to residency or inhabiting a restricted geographic area over an extended time, green turtles may temporarily, seasonally, or permanently live at a foraging ground when not migrating. Short-term tracking of green turtles has revealed areas of core use for routine purposes outside of migrations, such as preferred foraging or resting spots, within larger home ranges (Hart \& Fujisaki 2010). At Palmyra, for example, 4 hot spots or high-use zones were identified in the atoll's Southern and Northern Flats, as well as the Western and Central Lagoon and Flats, and Eastern Lagoon and Flats (Sterling et al. 2013) (see Fig. 1). Satellite tracking of immature turtles at their foraging grounds (Godley et al. 2003, McClellan \& Read 2009, Hart \& Fujisaki 2010, González Carman et al. 2012, Fukuoka et al. 2015, Williard et al. 2017) and of post-nesting females reaching these areas (Cheng 2000, Chan et al. 2003, Troëng et al. 2005, Hatase et al. 2006, Broderick et al. 2007, Seminoff et al. 2008, Scott et al. 2012, Balazs et al. 2015, Baudouin et al. 2015, Parker et al. 2015) emphasize residency close to food resources, as well as site fidelity, in which turtles return to the same foraging area (Godley et al. 2008, Balazs et al. 2015, Shimada et al. 2016). Further, adult green turtle satellite tracks substantially overlap with large and well-established MPAs (Scott et al. 2012).

Priority questions that guide marine turtle research (Hamann et al. 2010, Rees et al. 2016) remain largely unanswered with respect to the remote Central Pacific region, and male turtles in general (Godley et al. 2008). In this study, green turtles at Palmyra were flipper-tagged and satellite-tracked to evaluate residency in and spatial use of the Palmyra MPA and to inform management recommendations.

\section{MATERIALS AND METHODS}

\section{Study site}

The Palmyra Atoll National Wildlife Refuge $\left(5^{\circ} 53^{\prime} \mathrm{N}\right.$, $162^{\circ} 05^{\prime} \mathrm{W}_{\text {; Fig. }}$ 1) consists of $\sim 2.5 \mathrm{~km}^{2}$ of emergent land divided among several islets and $\sim 155 \mathrm{~km}^{2}$ of coral reefs, flats, and lagoons (Collen et al. 2009). The lagoons are connected by small channels and shallow areas with a maximum depth of $\sim 50 \mathrm{~m}$ in the Western Lagoon (Papastamatiou et al. 2010). There are steeply sloped fore-reefs to the north and south and gradually sloped reefs to the east and west. Directly off the atoll, there are steep plunges to initial depths of 200 to $2000 \mathrm{~m}$. The atoll's fish biomass including apex predators is substantial (Sandin et al. 2008, Williams et al. 2013, Smith et al. 2016). Reef habitat is comprised of wide, shallow, algae-rich reef flats and patch reefs also containing stony coral and crustose coralline algae. Turf algae, including green turtle forage species of Jania, Cladophora, and Spyridia, and macroalgae such as Bryopsis and Turbinaria, are abundant along the reef break and fore-reef (McFadden et al. 2010). Macroalgae-dominated communities are common around the atoll including species of Halimeda (calcareous green algae), Lobophora (brown algae), Dictyosphaeria (green algae), and Galaxaura and Dichotomaria (red algae) (Braun et al. 2008).

\section{Green turtle capture and tagging}

We captured green turtles at Palmyra for scientific research following permitted procedures (Sterling et al. 2013). Capture methods included using a scoop net, rodeo technique, or tangle nets, and took place in August 2008, August to September 2009, July 2010, July and August 2011, June to July 2012, and June to July 2013 (Sterling et al. 2013). Capture location by GPS coordinates and Palmyra zone designation (Fig. 1; Sterling et al. 2013) were noted for each turtle. Local time at Palmyra (GMT-10) was used for all analyses. Captured turtles were visually examined to determine species, sex (if apparent), body condition, and general health. We measured curved carapace length (CCL), curved carapace width (CCW), and tail length. We divided turtles into 3 size categories based on CCL: (1) juvenile $(<65 \mathrm{~cm})$; (2) subadult ( 65 to $84.9 \mathrm{~cm})$; and $(3)$ adult $(>85 \mathrm{~cm})($ Sterling et al. 2013). Turtles $\geq 85 \mathrm{~cm}$ CCL with tails $\geq 30 \mathrm{~cm}$ were classified as males, with the caveat that sex was not determined laparoscopically and testes maturity could not be discerned (Hamann et al. 2003, Sterling et al. 2013). However, due to tail size, 1 satellitetracked individual (23513) and 4 flipper-tagged turtles were classified as male despite having $<85 \mathrm{~cm}$ CCL and being categorized as subadults. All captured animals were tagged with numbered Inconel flipper tags on the front flippers and subcutaneous 


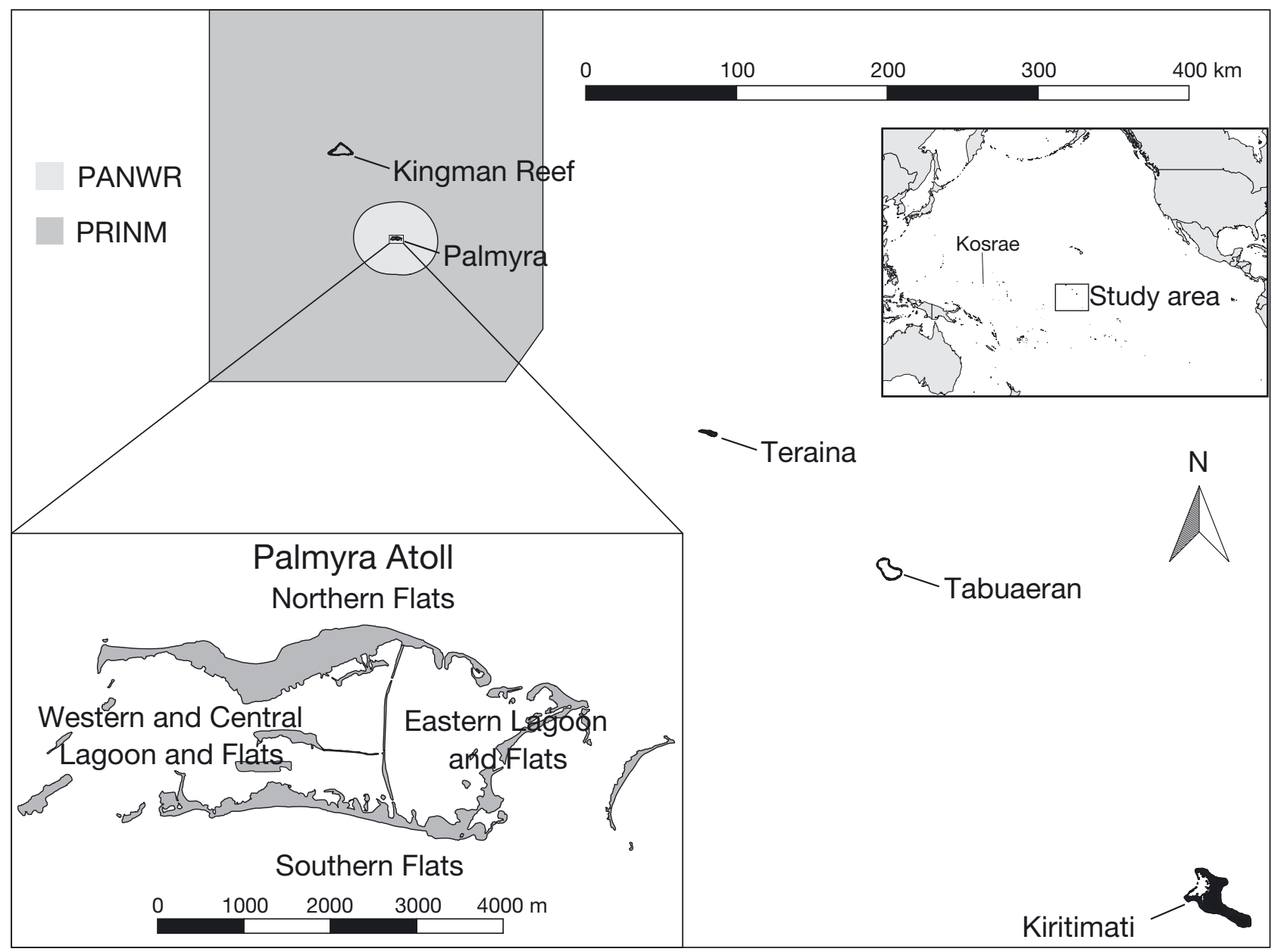

Fig. 1. Palmyra Atoll, Northern Line Islands, USA; study site is shown with respect to boundaries of the Palmyra Atoll National Wildlife Refuge (PANWR) and as part of the Pacific Remote Island National Monument (PRINM) in the Central Pacific Ocean. Also shown are the sites of 2 green turtle flipper-tag recoveries, one at Kiritimati (Northern Line Islands, Republic of Kiribati), where there is a small green turtle rookery, and one in Kosrae, Micronesia, where nesting has not been documented (Maison et al. 2010, Trevor 2010). Lower inset: 4 major zones where green turtles were captured at Palmyra: Northern Flats, Southern Flats, Western and Central Lagoon and Flats, and Eastern Lagoon and Flats

passive integrated transponder (PIT) tags on the hind flippers, photographed, and released at or near the capture site (Sterling et al. 2013). Mortality events, when observed, were recorded by refuge staff or researchers.

To provide a general baseline on movements, data-archiving satellite transmitters set to an active duty cycle of $24 \mathrm{~h}$ were attached using epoxy to a subset of turtles captured in 2008 (3 males, 1 female, 2 subadults) (Table 1). Of these, 1 subadult (85945) and 1 male (85946) received highly precise MK10-AFB Fastloc GPS tags (Table S1 in the Supplement at www.int-res.com/articles/suppl/n037 p165_supp.pdf). From 2009 to 2013 the study shifted entirely to turtles identified as males ( $\mathrm{n}=$ 12; Table 1), since comparatively little was known about their movements (Godley et al. 2008), and males tend to depart on breeding migrations more frequently than females (Limpus 1993, Hays et al. 2010).

\section{Satellite tracking and data filtering}

The Argos-CLS data were stored and filtered for location quality using the Satellite Tracking and Analysis Tool (STAT) program available at www. seaturtle.org (Coyne \& Godley 2005). Argos provided the positional data accuracy specified as location classes (LCs) 3, 2, 1, 0, A, B, and Z (Table S1 in the Supplement). LCs A and B have no accuracy estimates supplied by Argos, but LC A accuracy 
Table 1. Data on satellite-tracked green turtles at Palmyra Atoll. Included are the Argos transmitter identification number, Palmyra capture and release zone, sex $(\mathrm{M}=$ male, $\mathrm{F}=$ female, $\mathrm{U}=$ unknown), curved carapace length (CCL) and width (CCW), and mass, with mean and standard deviation (SD). Release, recapture (if applicable), and final transmission dates are given (in MM/DD/YY), along with transmission duration. The capture and release zone is labeled as per Fig. 1. Residency areas on the Atoll of the individual or grouped (all turtles, all males, or by field year) satellite-tracked turtles were calculated from best daily locations using location classes (LC) 1, 2, or 3 Argos data, or from earliest daily locations for Fastloc GPS data. Calculations were based on minimum convex polygon (MCP), kernel density (KDE), grid density estimation (Hexagon grid), and time-local convex hulls (T-LoCoh), except for turtles 93344, 93341, 54162, and 106302 that lacked in sufficient fine-scale data

\begin{tabular}{|c|c|c|c|c|c|c|c|c|c|c|c|c|c|c|c|c|}
\hline \multirow{3}{*}{ Argos ID } & \multirow{3}{*}{$\begin{array}{l}\text { Palmyra } \\
\text { zone }\end{array}$} & \multirow{3}{*}{ Sex } & \multicolumn{2}{|c|}{ - Turtle data } & \multirow{3}{*}{$\begin{array}{c}\text { Mass } \\
(\mathrm{kg})\end{array}$} & \multirow{3}{*}{$\begin{array}{c}\text { Release } \\
\text { date }\end{array}$} & \multirow{3}{*}{$\begin{array}{c}\text { Recap. } \\
\text { date }\end{array}$} & \multicolumn{2}{|c|}{ Transmissions } & \multirow{3}{*}{$\mathrm{MCP}$} & \multirow{2}{*}{\multicolumn{2}{|c|}{$\begin{array}{l}\mathrm{Re} \\
\mathrm{KDE}(\%)\end{array}$}} & \multirow{2}{*}{\multicolumn{2}{|c|}{$\begin{array}{l}\text { idency }\left(\mathrm{km}^{2}\right) \\
\text { T-locoh }(\%)\end{array}$}} & \multirow{2}{*}{\multicolumn{2}{|c|}{ Hexagon grid }} \\
\hline & & & $\mathrm{CCL}$ & $\mathrm{CCW}$ & & & & \multirow{2}{*}{$\begin{array}{l}\text { Final } \\
\text { date }\end{array}$} & \multirow{2}{*}{$\begin{array}{l}\text { Total } \\
\text { days }\end{array}$} & & & & & & & \\
\hline & & & $(\mathrm{cm})$ & $(\mathrm{cm})$ & & & & & & & 50 & 95 & 50 & 95 & $>75$ & $\leq 75$ \\
\hline 2008 & & & & & & & & & & & & & & & & \\
\hline 85923 & Western & $\mathrm{U}$ & 73.0 & 67.5 & 46.8 & 08/10/08 & & 02/24/09 & 197 & 1.4 & 0.1 & 1.3 & 0.0 & 0.4 & 0.2 & 1.1 \\
\hline 23513 & Southern & M & 75.2 & 69.2 & 56.8 & 08/13/08 & & 05/07/09 & 267 & 8.5 & 1.4 & 4.8 & 0.3 & 2.6 & 0.2 & 3.2 \\
\hline 85924 & Southern & $\mathrm{M}$ & 87.0 & 80.5 & 71.8 & 08/13/08 & & 05/09/10 & 633 & 109.4 & 2.1 & 14.9 & 1.6 & 10.2 & 0.3 & 12.4 \\
\hline 85946 & Western & M & 94.5 & 85.0 & 94.2 & 08/14/08 & & $10 / 23 / 08$ & 68 & 0.5 & 0.2 & 1.5 & 0.0 & 0.1 & 0.2 & 0.9 \\
\hline 85945 & Northern & $\mathrm{U}$ & 81.0 & 72.2 & 52.8 & 08/20/08 & & $11 / 12 / 08$ & 84 & 7.7 & 0.2 & 3.6 & 0.1 & 1.8 & 0.2 & 2.3 \\
\hline 85922 & Western & $\mathrm{F}$ & 85.5 & 78.0 & 66.9 & 08/23/08 & $06 / 21 / 13$ & $10 / 13 / 08$ & 51 & 0.4 & 0.1 & 0.3 & & & 0.0 & 0.5 \\
\hline 2009 & & & & & & & & & & & & & & & & \\
\hline 85921 & Eastern & M & 96.0 & 86.5 & 107.3 & 08/25/09 & & 09/25/10 & 396 & 80.3 & 5.4 & 20.6 & 5.0 & 33.0 & 0.3 & 12.7 \\
\hline $\begin{array}{l}85920 \\
\text { on atoll }\end{array}$ & Southern & M & 88.7 & 80.9 & 74.4 & 08/26/09 & 07/19/10 & 02/07/11 & 530 & 15.7 & 1.2 & 6.6 & 1.1 & 7.2 & 0.3 & 3.6 \\
\hline 93344 & Southern & M & 85.0 & 78.5 & 80.0 & 08/28/09 & & 10/31/09 & 64 & - & - & - & - & - & - & - \\
\hline 93342 & Northern & M & 96.5 & 96.2 & 101.0 & 08/31/09 & & 12/08/09 & 98 & 0.7 & 0.1 & 0.3 & - & - & 0.0 & 0.6 \\
\hline 93343 & Northern & M & 96.2 & 86.3 & 97.5 & 08/31/09 & & 11/04/09 & 64 & 1.4 & 0.3 & 0.8 & 0.1 & 0.6 & 0.2 & 0.8 \\
\hline 93341 & Western & M & 91.8 & 87.5 & 86.0 & 09/02/09 & & $05 / 04 / 10$ & 243 & - & - & - & - & - & - & - \\
\hline 2010 & & & & & & & & & & & & & & & & \\
\hline 54162 & Western & M & 85.3 & 85.0 & 89.0 & 07/18/10 & & 08/31/10 & 43 & - & - & - & - & - & - & - \\
\hline 2011 & & & & & & & & & & & & & & & & \\
\hline 54158 & Western & M & 94.1 & 91.2 & 98.6 & $07 / 24 / 11$ & & $02 / 05 / 13$ & 561 & 16.3 & 1.4 & 5.4 & 1.5 & 10.4 & 0.2 & 4.2 \\
\hline 106301 & Western & M & 99.6 & 90.4 & 119.4 & $07 / 24 / 11$ & & $10 / 07 / 12$ & 440 & 14.2 & 2.1 & 4.4 & 1.0 & 7.0 & 0.2 & 3.4 \\
\hline 106300 & Northern & M & 94.0 & 83.3 & 83.8 & $07 / 26 / 11$ & & 09/02/11 & 37 & 4.1 & 0.5 & 0.8 & 0.4 & 2.7 & 0.0 & 1.1 \\
\hline 106302 & Western & M & 89.1 & 80.6 & 81.2 & $08 / 12 / 11$ & & $11 / 05 / 11$ & 84 & - & - & - & - & - & - & - \\
\hline 2012 & & & & & & & & & & & & & & & & \\
\hline 36501 & Eastern & M & 90.0 & 78.2 & 77.8 & 07/10/12 & $06 / 28 / 13$ & $02 / 12 / 13$ & 216 & 3.5 & 0.5 & 1.1 & 1.1 & 1.7 & 0.9 & 0.2 \\
\hline Totals & & & & & & & & & & & & & & & & \\
\hline 08/08-07/09 & & & & & & & & & & 54.8 & 3.3 & 17.6 & 6.3 & 16.1 & 0.5 & 11.4 \\
\hline 08/09-07/10 & & & & & & & & & & 146.0 & 3.7 & 26.6 & 6.9 & 50.8 & 0.2 & 17.4 \\
\hline $08 / 10-07 / 11$ & & & & & & & & & & 12.4 & 1.3 & 2.3 & 4.4 & 9.8 & 0.2 & 2.5 \\
\hline $08 / 11-07 / 12$ & & & & & & & & & & 38.4 & 4.3 & 10.9 & 4.3 & 22.2 & 0.3 & 7.4 \\
\hline All males & & & & & & & & & 3744 & 186.4 & 5.7 & 44.4 & 8.1 & 55.8 & 0.5 & 32.4 \\
\hline Mean & & & 90.9 & 84.0 & 87.9 & & & & 249.6 & & & & & & & \\
\hline & & & 6.2 & 6.5 & 15.6 & & & & 210.8 & & & & & & & \\
\hline All turtles & & & & & & & & & 4076 & 186.4 & 6.0 & 44.8 & 8.3 & 55.7 & 0.5 & 33.5 \\
\hline Mean & & & 89.0 & 82.1 & 82.5 & & & & 226.4 & & & & & & & \\
\hline $\mathrm{SD}$ & & & 7.3 & 7.5 & 19.2 & & & & 200.3 & & & & & & & \\
\hline
\end{tabular}

is reportedly lower than LC 1 (Hazel 2009, Hoenner et al. 2012). Argos positions were filtered and excluded if swim speed exceeded $5 \mathrm{~km} \mathrm{~h}^{-1}$ or if the LC was Z (Table S1 in the Supplement). The Wildlife Computers online portal was used for the 2 MK10-AFB Fastloc GPS tagged turtles (Table S1 in the Supplement). Fastloc GPS positions are reportedly accurate to between 20 and $75 \mathrm{~m}$, although the linear error can exceed $75 \mathrm{~m}$ (Hazel 2009, Dujon et al. 2014).

\section{Spatial analysis}

Residency calculations were carried out using 4 different methods in R (R Core Team 2016) and spatial analysis tools in QGIS 2.16 (QGIS 2016). For these fine-scale analyses, Argos data were additionally filtered to include only the most accurate, or LC 1,2 , and 3 classes of positions, that fell on water. To avoid spatial autocorrelation, the single best daily location of highest LC quality was used (Doherty et 
al. 2017). For the Fastloc-tagged turtles, on days with multiple locations, only the earliest known position for each day was considered (Table S1 in the Supplement). The mapped locations in STAT provided sea surface temperature (SST) and estimated turtle displacement, which was calculated from the summed straight-line distance between accepted positions.

For comparison to past studies, the minimum convex polygon (MCP), also considered to be the home range (Burt 1943), was calculated. In addition, highuse areas were characterized through widely employed kernel density estimations (KDEs). KDEs encompassing 50 and $95 \%$ of the positional data were used to calculate core-use and home range areas, respectively (Hart \& Fujisaki 2010). KDE point densities were determined per $0.25 \mathrm{~km}^{2}$ unit and densities were classified under 4 classes of different quantiles. The bandwidth, which smooths and determines the kernel size (Gitzen et al. 2006), was the same as the resolution of the cell size $\left(0.25 \mathrm{~km}^{2}\right)$. The third method, a hexagon sampling grid, was used to map the proportional use of each hexagon. Hexagons were $0.154 \mathrm{~km}^{2}$ in area and covered the larger Palmyra Atoll site. Hexagon size was determined by applying the same hexagon grid across all turtle ranges using 8000 hexagons to fill the study area. Fourth, through local convex hull ( $\mathrm{LCH})$ procedures, local MCPs were aggregated, sorted, and combined to make isopleths using the $\mathrm{R}$ package $\mathrm{T}-\mathrm{LoCoH}$ (Lyons et al. 2013). LCH uses an optimal number of nearest neighbors determined through reducing errors of commission and omission.

Comparisons of space-use were made using the utilization distribution overlap index (UDOI) for all turtle pairs through the $\mathrm{R}$ package adehabitatHR (Calenge 2006). UDOI describes the space-use comparison between 2 utilization distributions of individuals where kernel densities are estimated, and density grids are compared across the usable space. Values can range from 0 (no overlap) to 1 (entire overlap, and identical distributions). Values $>1$ are observed when the overlap is higher than uniform space-use overlap (Fieberg \& Kochanny 2005). Lastly, space-use was measured by comparing the true track of an individual to 1000 random tracks and tested for significance as determined by the sum of least-squares $\mathrm{p}$-values in the $\mathrm{R}$ package adehabitatLT (Calenge 2006). Random tracks were generated for each turtle beginning at its starting position and randomizing the angles between occurrences (source code available at https://github.com/dnbucklin/r_movement_homerange/blob/master/site_fidelit Y_test.r). Since turtles rarely left the vicinity of Pal- myra Atoll, the tracks were constrained to an area of $10 \mathrm{~km}$ around the atoll. The tracks were randomized such that the random track's distance was equal to that of each turtle's true track.

\section{RESULTS}

\section{Green turtle flipper-tagging}

We flipper-tagged 555 green turtles with Inconel and PIT tags from 2008 to 2013. Of the 555 turtles captured, we had CCL measurements for 554, and the average CCL was $69.86 \mathrm{~cm}$ (range $=40.3$ to $113.6 \mathrm{~cm}$ ). Following Sterling et al. (2013), a total of $123(22.2 \%)$ were classified as adults (CCL $\geq$ $85 \mathrm{~cm}$ ), with 45 assigned as male, 32 as female, and the remainder of unknown sex. Further, 193 turtles $(34.8 \%)$ were considered to be subadults and $43 \%$ were juveniles. Of these, 59 individuals were recaptured on site, with 4 turtles recaptured twice, and 2 turtles recaptured 3 times for a total of 67 flipper-tag recaptures (Table 2). Four individuals flipper-tagged in 2008, including the satellite-tracked female (85922), were recaptured at Palmyra in 2013. Of the recaptures, $81 \%$ occurred in the zone where the turtle was originally tagged. No turtles tagged elsewhere were recaptured on the atoll.

Two turtles with Inconel flipper tags were recovered away from Palmyra (Fig. 1); one at Kiritimati (Northern Line Islands), where there is a small green turtle rookery, and one in Kosrae, Micronesia, where nesting has not been documented (Maison et al. 2010, Trevor 2010). The individual captured in Kiritimati had been classified as female based on tail length $(<30 \mathrm{~cm})$ and carapace measurements $(\mathrm{CCL} \geq$ $85 \mathrm{~cm}$ ) when tagged at Palmyra in 2011. The tag recovery was reported in 2015 but the date of recovery is uncertain and occurred when the turtle was captured for food. Similarly, the individual captured in Kosrae was offered for sale in 2017. When captured on Palmyra in 2009, this subadult had front flipper damage, with both flippers missing above the claw. This study's tally of observed green turtle mortality consists of these 2 flipper-tagged turtles, and 9 carcasses without flipper tags recorded at Palmyra since 2006.

\section{Satellite tracking and analysis}

The turtles fitted with satellite transmitters ranged from 73.0 to $99.6 \mathrm{~cm}$ CCL $($ mean $=88.7 \mathrm{~cm}$; Table 1$)$. 
Table 2. Mark-recapture data from green turtles marked with Inconel and PIT tags at Palmyra Atoll. The number of turtles (males, females, and juveniles/subadults) tagged and recaptured in each of the 4 zones on Palmyra during the 2008-2013 study is given. No turtles were recaptured in 2008 or 2009. Recapture numbers in parentheses are individuals that were caught in a different zone than the one in which they were originally captured and tagged; zones are labeled as per Fig. $1-$ N: Northern Flats; S: Southern Flats; W: Western and Central Lagoon and Flats; E: Eastern Lagoon and Flats

\begin{tabular}{|c|c|c|c|c|c|c|c|c|c|c|c|}
\hline \multirow{2}{*}{$\begin{array}{l}\text { Stage/ } \\
\text { sex }\end{array}$} & \multirow[t]{2}{*}{ Zone } & \multirow{2}{*}{$\begin{array}{c}2008 \\
\text { No. } \\
\text { tagged }\end{array}$} & \multirow{2}{*}{$\begin{array}{c}2009 \\
\text { No. } \\
\text { tagged }\end{array}$} & \multicolumn{2}{|c|}{$-2010-$} & \multicolumn{2}{|c|}{$-2011 \longleftarrow$} & \multicolumn{2}{|c|}{$-2012 \longleftarrow$} & \multicolumn{2}{|c|}{2013} \\
\hline & & & & $\begin{array}{c}\text { No. } \\
\text { tagged }\end{array}$ & Recaptured & $\begin{array}{c}\text { No. } \\
\text { tagged }\end{array}$ & Recaptured & $\begin{array}{c}\text { No. } \\
\text { tagged }\end{array}$ & Recaptured & $\begin{array}{c}\text { No. } \\
\text { tagged }\end{array}$ & Recaptured \\
\hline \multirow{4}{*}{$\begin{array}{l}\text { Adult } \\
\text { males }\end{array}$} & $\mathrm{N}$ & 0 & 2 & 1 & 0 & 1 & 0 & 2 & 0 & 1 & $(1)$ \\
\hline & $\mathrm{S}$ & 5 & 2 & 1 & 1 & 0 & 0 & 1 & 0 & 0 & (1) \\
\hline & $\mathrm{E}$ & 0 & 1 & 1 & 0 & 0 & 0 & 4 & 0 & 2 & $1(1)$ \\
\hline & $\mathrm{W}$ & 1 & 2 & 3 & 0 & 4 & 0 & 5 & 0 & 7 & 0 \\
\hline \multirow{4}{*}{$\begin{array}{l}\text { Adult } \\
\text { females }\end{array}$} & $\mathrm{N}$ & 0 & 2 & 1 & 0 & 0 & 0 & 1 & $1(1)$ & 3 & 1 \\
\hline & $\mathrm{S}$ & 0 & 0 & 0 & 0 & 0 & 0 & 0 & 0 & 2 & 0 \\
\hline & $\mathrm{E}$ & 0 & 1 & 3 & 0 & 0 & 0 & 0 & 0 & 1 & 2 \\
\hline & W & 1 & 6 & 2 & 0 & 2 & 0 & 19 & $2(1)$ & 15 & $7(1)$ \\
\hline \multirow{5}{*}{$\begin{array}{l}\text { Juveniles/ } \\
\text { subadults } \\
\text { (sex } \\
\text { unknown) } \\
\text { Total }\end{array}$} & $\mathrm{N}$ & 16 & 7 & 3 & 0 & 13 & 1 & 29 & 0 & 16 & 4 \\
\hline & $\mathrm{S}$ & 5 & 8 & 11 & 1 & 15 & 2 & 12 & 0 & 20 & $3(1)$ \\
\hline & $E$ & 7 & 9 & 15 & 2 & 22 & 3 & 66 & $4(1)$ & 61 & $12(4)$ \\
\hline & W & 6 & 9 & 2 & 0 & 21 & 1 & 30 & 0 & 47 & $6(1)$ \\
\hline & & 41 & 49 & 43 & 4 & 78 & 7 & 169 & 10 & 175 & 46 \\
\hline
\end{tabular}

In total, 7586 Argos locations were obtained from the complete range of accepted LCs, in addition to 173 Fastloc GPS positions (Tables 1 \& S1). Tracking duration for all turtles (including 2 subadults and 1 female; $\mathrm{n}=18)$, as well as for males only $(\mathrm{n}=15)$, ranged from 37 to $633 \mathrm{~d}$, with a mean of $227 \mathrm{~d}$ for all turtles and $250 \mathrm{~d}$ for males. The Fastloc GPS technology provided significantly more high-quality locations but lasted for shorter periods (Tables $1 \& \mathrm{~S} 1$ ).

With the exception of 1 male, all of the satellitetracked turtles remained within refuge boundaries for the entire tracking duration. Five turtles visually identified as males were tracked for over 1 yr (Table 1). Three of the 18 satellite-tracked turtles were recaptured at Palmyra: male 85920 before leaving the atoll, as well as male 36501 and female 85922 in 2013 after transmissions ended (Table 1).

After the second round of fine-scale filtering described above, residency patterns were estimated for 14 turtles, of which 11 were male (Table 1). These turtles stayed close to capture and release sites $(\sim 2 \mathrm{~km}$ displacement, range $=0.8$ to $3.6 \mathrm{~km})$, nearshore $($ mean $=0.75 \mathrm{~km}$, range $=0.70 \mathrm{~m}$ to $20 \mathrm{~km}$ distance from shore), and within a narrow SST range $\left(24.5\right.$ to $30.8^{\circ} \mathrm{C}$, mean $\left.=27.8^{\circ} \mathrm{C}\right)$. They generally remained in shallow waters, although a few off-atoll positions were in the vicinity of sharp drop-offs. High-use areas were detected along the Southern, Northern, and Eastern Lagoon and Flats, as well as the Western and Central Lagoon and Flats, where higher concentrations of larger and heavier turtles had been previously noted (Sterling et al. 2013).
Within these zones, spatial and temporal overlap of tracks was evident, and spatial overlap between adjacent zones was observed (Figs. 2, 3, \& S1-S6 in the Supplement).

The UDOI for all pairwise turtle comparisons ranged from 0.000 to 1.210 (mean $=0.173, \mathrm{SD}=$ 0.220 ). The lowest UDOI was from turtles with tags 54158 and 36501, which had completely non-overlapping MCPs and KDEs concentrated on the Western (54158) and Southern (36501) portions of the Atoll (Figs. 2A \& S2). In contrast, the highest UDOI was from turtles with tags 23513 and 85924, which had overlapping MCPs and similar KDEs indicating high congruence of these individuals in their range utilization. Of the 14 turtles from which we collected data, 12 turtles' space-use was more likely to be near the initial position as revealed by sum of leastsquares p-values of $<0.001$, with the sums of least squares being lower than in the random walk. Two males with tags 106300 and 93342, despite spatially restricted positions close to the atoll, were not more likely to be found near their initial position but had very few overall positions. All other turtles showed high site fidelity as revealed by sum of least-squares p-values of $<0.001$, with the sums of least squares being lower than in the random walk.

One turtle, male 85920, remained at Palmyra for over $1 \mathrm{yr}(\sim 388 \mathrm{~d})$ and then departed in September 2010 for a total distance traveled of $5614 \mathrm{~km}$ (Fig. 4). This track revealed continuous movement within a narrow SST range $\left(24.5\right.$ to $28.9^{\circ} \mathrm{C}$, mean $\left.=26.4^{\circ} \mathrm{C}\right)$ and over deep water. The circular loop's clockwise 


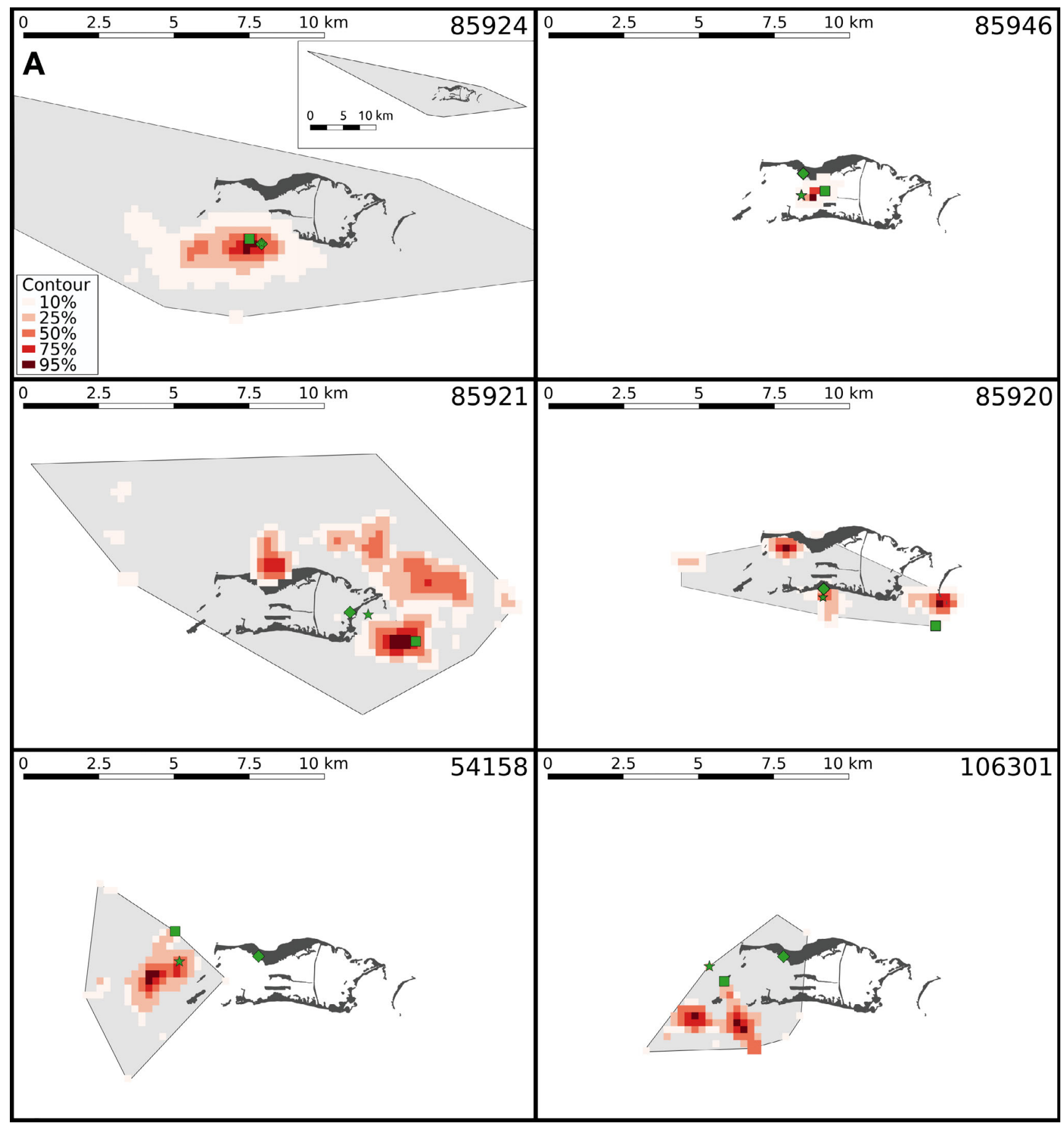

Fig. 2. Residency patterns of select satellite-tracked male green turtles, with contour percentages. (A) Minimum convex polygon (gray) and kernel density (MCP/KDE), (B) grid density estimation (hexagon grid), and (C) time-local convex hulls (TLoCoh) maps are shown for turtles 85924, 85946 (Fastloc GPS), 85921, 85920 (on atoll), 54158, and 106301, which were the turtles with most data (Table 1). The remaining individuals are depicted in Figs. S1-S6 in the Supplement. Green symbols in Fig. 2A represent capture (star), release (diamond), and final transmission (square) sites

Fig. 2 continued on the next two pages

direction appeared to match prevailing surface currents. There were no extended stops near nesting beaches nor courtship areas where mating might occur. The turtle did approach Tabuaeran (Northern Line Islands, Fig. 4), where marine turtle nesting has been recorded (Maison et al. 2010). 


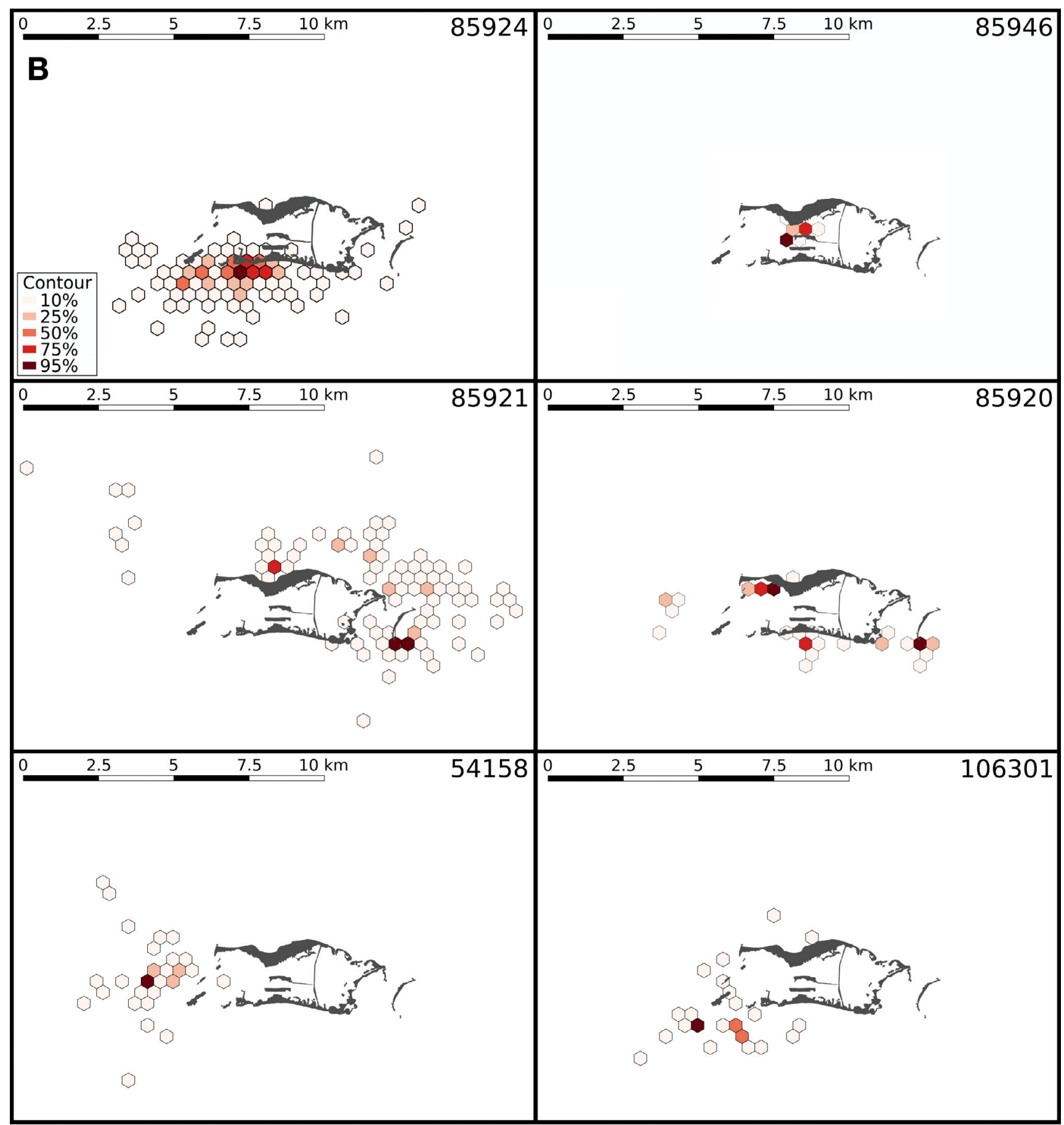

Fig. 2 (continued)

\section{DISCUSSION}

This study on residency of regionally endangered green turtles foraging at the Palmyra Atoll National Wildlife Refuge highlights the importance of this remote, well-protected area, which provides within its boundaries respite from fishing and other pervasive human influence. Key knowledge gaps were bridged by focusing on the under-characterized Central Pacific region, as well as very rarely tracked male marine turtles (Godley et al. 2008). Green turtle movements were revealed to be almost fully con- 


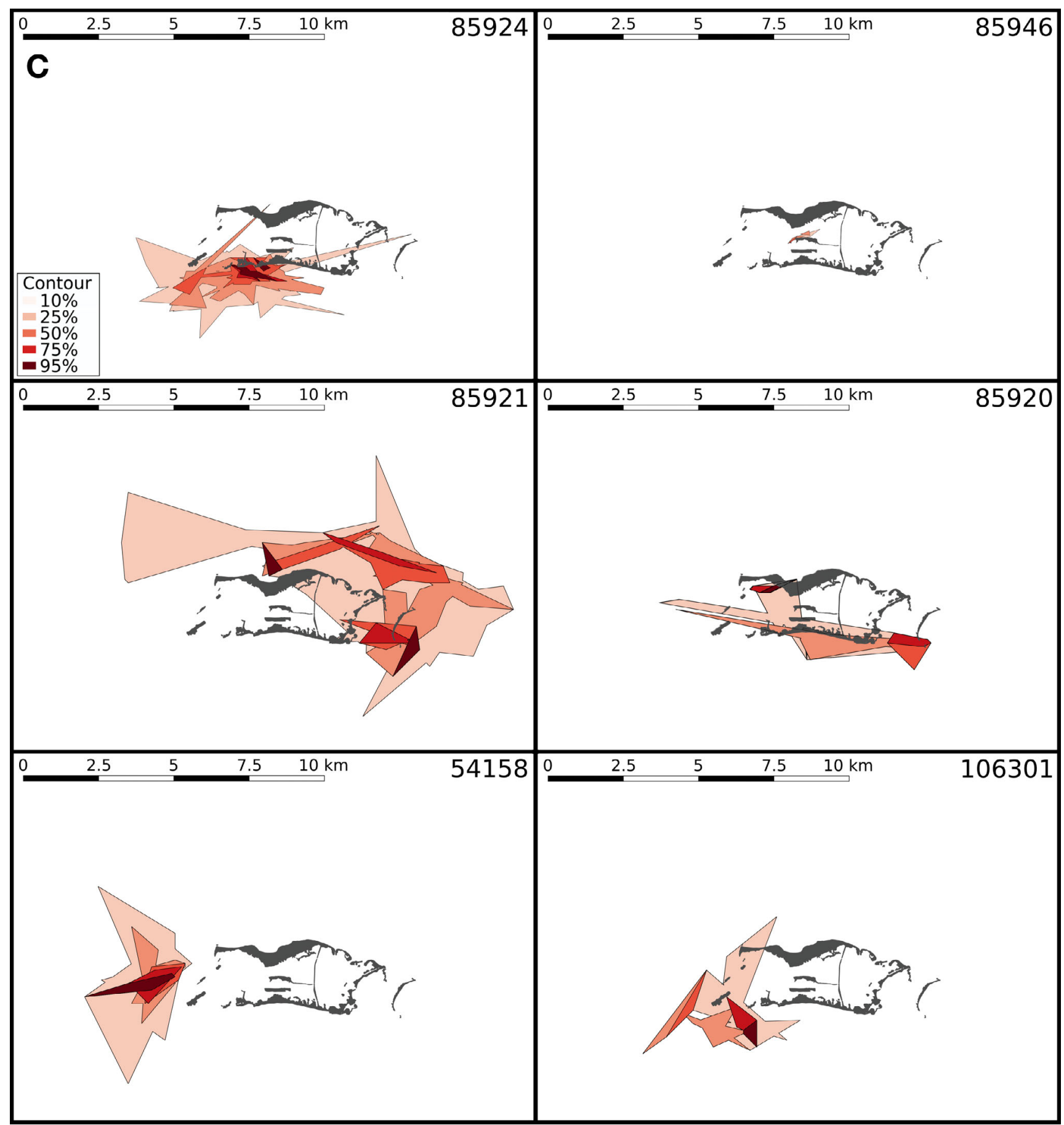

Fig. 2 (continued)

tained within the refuge, close to food resources and the shore, supporting the idea of long-term residency and site fidelity. Further, males tracked for more than 1 yr did not undertake annual breeding migrations. The study did, however, document 3 departures from the Palmyra Atoll National Wildlife Refuge, support- ing previously noted links to Micronesia (NaroMaciel et al. 2014) while uncovering new connectivity to the Northern Line Islands. Priority research questions were thus addressed, underscoring the broader utility of reserves as marine conservation cornerstones. 

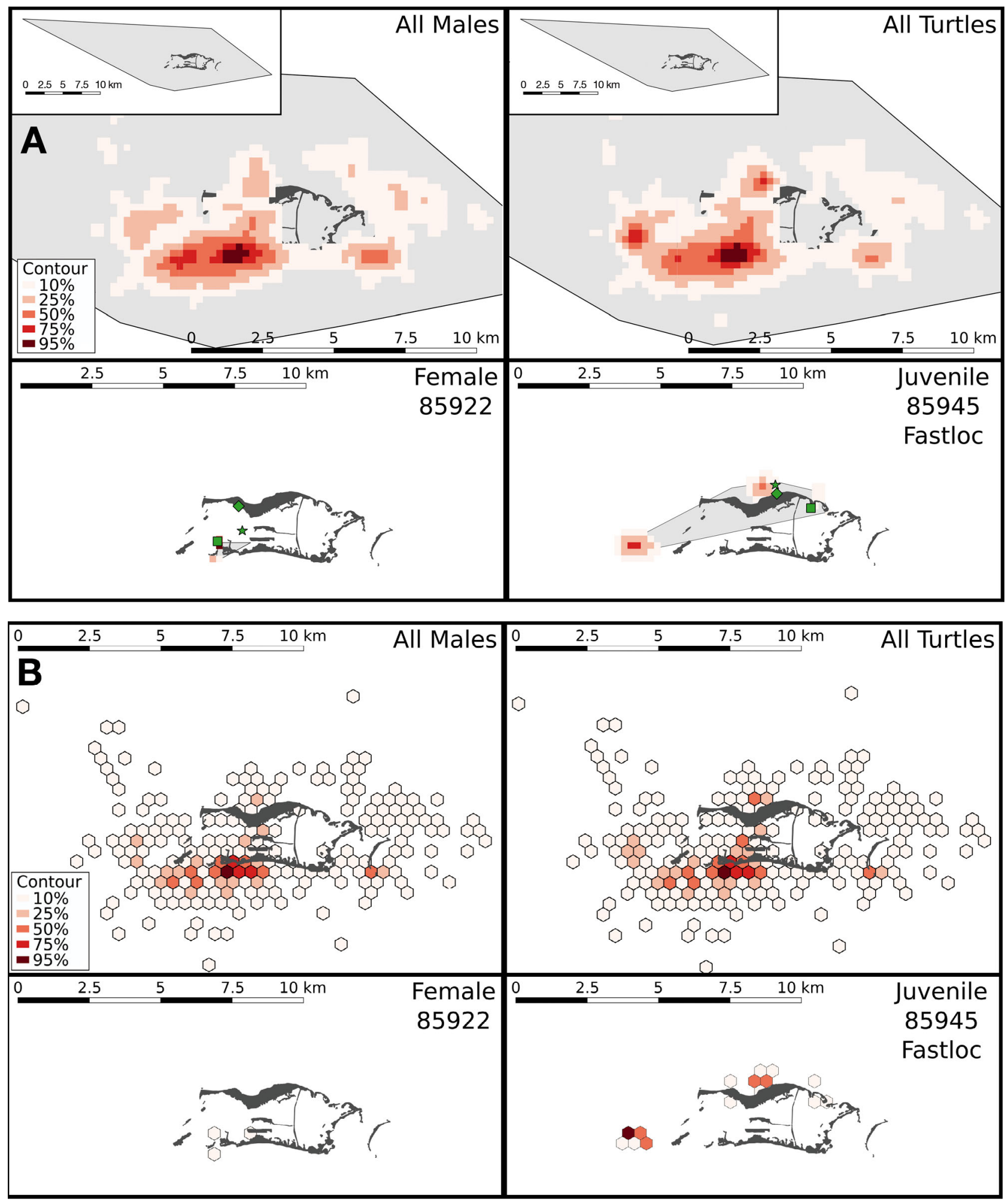

Fig. 3. Residency patterns of satellite-tracked green turtles. (A) Minimum convex polygon (gray) and kernel density (MCP/ $\mathrm{KDE}$ ), (B) grid density estimation (hexagon grid), and (C) time-local convex hull analysis (T-LoCoh), are shown for turtles as follows: all males, all turtles, female 85922 (there was insufficient data for T-LoCoh estimates), and subadult 85945 (Fastloc GPS). Insets in Fig. 3A: MCP estimates at a greater distance. Green symbols in Fig. 3A represent capture (star), release (diamond), and final transmission (square) sites 


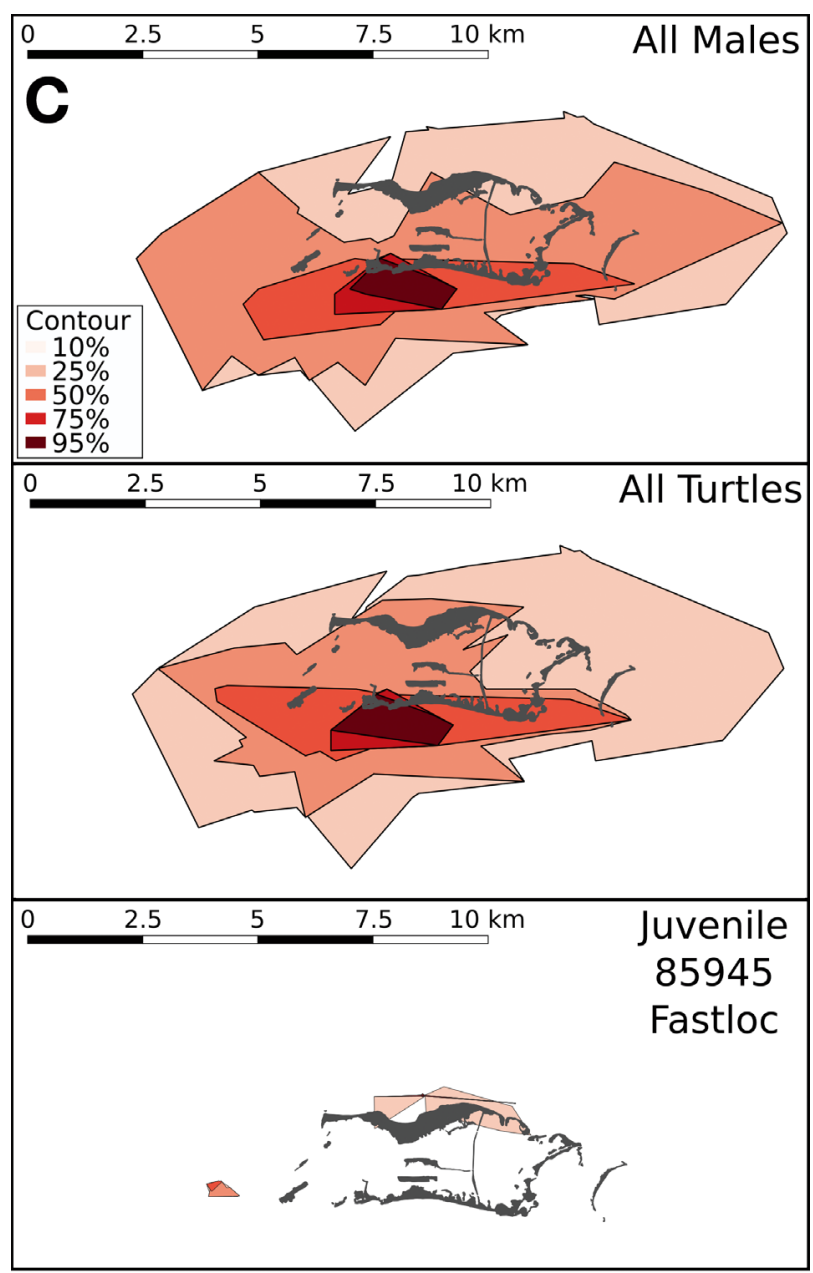

Fig. 3 (continued)

\section{Green turtle residency at Palmyra, with a focus on males}

High-quality habitats, where energy expenditure to gain resources or avoid threats is minimized, are predictors of extended residency, small home ranges, and low turnover for many animals (Winker et al. 1995, Griffen \& Drake 2008). These patterns are also consistent with marine megafaunal behavior in remote, spatially restricted areas such as Palmyra that contain substantive food and other resources (Karczmarski et al. 2005, Papastamatiou et al. 2010, 2012, Barnett et al. 2012). The small atoll is considered a quality habitat for green turtles (Sterling et al. 2013) and other marine vertebrates (Papastamatiou et al. 2010, 2012). Green turtles are among the animal species predicted to aggregate in high-quality, low-threat areas including large reserves with strict measures such as Palmyra (Scott et al. 2012, Sterling et al. 2013, Doherty et al. 2017). Local residency constitutes 1 of 4 general patterns observed in marine turtle satellite tracking studies (Plotkin et al. 1996, Hays et al. 2001, Shaver et al. 2005, Godley et al. 2008), and extended residence at foraging sites can enhance survival and reproduction through consistent access to food combined with predator familiarity and avoidance (Shimada et al. 2016).

Spatial isolation and lack of human impact likely contribute to the habitat quality observed at Palmyra, along with environmental factors. For green turtles, seasonal movements generally occur when temperature differences are more pronounced and may lead to dangerous cold-stunning events (Shimada et al. 2016). In contrast, temperatures at the near-equatorial Palmyra fall within a narrow range suitable for this species and well above the $15^{\circ} \mathrm{C}$ approximate threshold for dormancy or migration (Williard et al. 2017). Palmyra further offers abundant algal resources, including common components of green turtle diets, although the extent of competition for these remains to be determined (McFadden et al. 2010). With respect to threats, the atoll's green turtles are free of fibropapillomatosis disease and are protected from fishery activity or habitat alteration prohibited within the refuge (Sterling et al. 2013).

In contrast, sharks are common predators at Palmyra, also predating on green turtles, as revealed by missing flippers and bite-shaped carapace damage (Sterling et al. 2013). Given the relatively low mark-recapture rate, unobserved mortality by natural predators cannot be excluded. There was also evidence of recovery from shark attacks. For example, satellite-tracked female 85922 had a large, healed shark bite when first caught in 2008 and was still in an otherwise healthy condition when recaptured in 2013. Shark predation decreases as turtles become larger and less vulnerable, and there is plentiful alternate prey for sharks on Palmyra.

This study represents one of the largest single data sets on satellite-tracked male green turtles and complements substantive conventional tagging efforts to reveal restricted residency at Palmyra. With the caveat that sex and reproductive maturity were not determined laparoscopically, the presumed male green turtles that we tracked used most of the atoll (Figs. 3 \& S1-S6), including previously noted highuse areas (Sterling et al. 2013), with a concentration on the Southern Flats. Displacement of individual turtles, however, was generally restricted and constrained mostly to shallow waters that were close to 


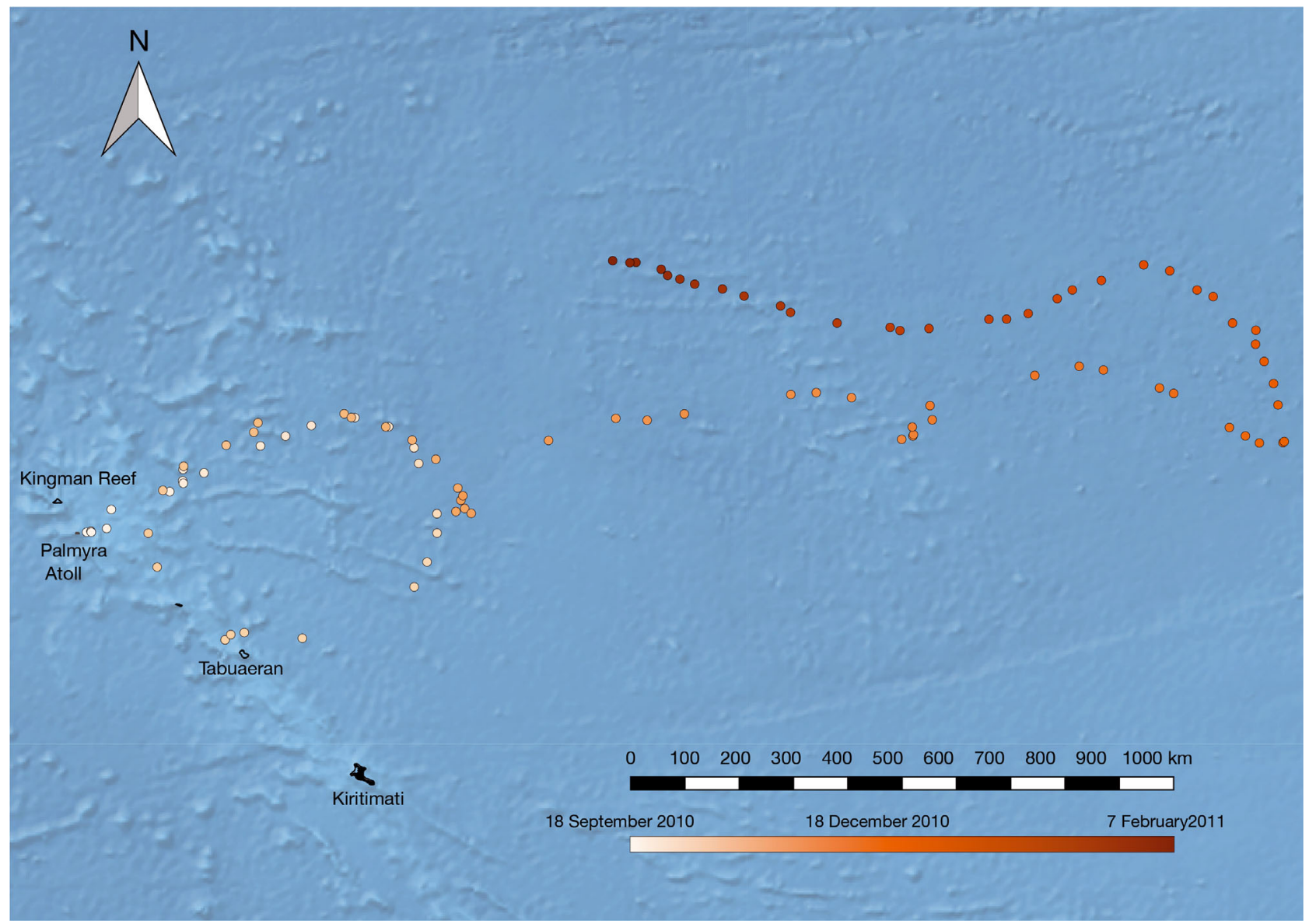

Fig. 4. Satellite telemetry of male green turtle 85920 after leaving Palmyra Atoll until transmissions ceased $141 \mathrm{~d}$ later. Locations are shown with respect to the Northern Line Islands of Kiritimati and Tabuaeran, where there are green turtle rookeries. Bathymetry relief is indicated and tracking dates are coded as a gradient, with lighter colors representing earlier dates. The sum distance of each location indicates this turtle traveled $\sim 5600 \mathrm{~km}$. Made with Natural Earth. Free vector and raster map data at naturalearthdata.com

food resources and the shore. The only other study known to us that includes adult green males at foraging grounds (Shimada et al. 2016) confirms markrecapture findings of long-term site fidelity and spatially restricted residency, outside of seasonal or breeding migrations (Limpus et al. 1992, Limpus 1993, Craig et al. 2004). Although these males, tracked in Australia, ceased transmission sooner than those in our study, no significant differences were detected between male and female residency patterns except that males bred more frequently than females, supporting previous findings (Limpus 1993, Godley et al. 2008). However, this rare documentation of 5 male tracks lasting over a year does not support male annual breeding migrations observed elsewhere (Limpus 1993, Hays et al. 2010), and suggests that Palmyra males may depart less frequently on breeding migrations, or perhaps mate at the refuge itself.
Evidence has been found that male green turtles in Cyprus also do not exhibit annual breeding behaviors (Wright et al. 2012).

The Palmyra tagging and tracking data confirmed limited movements of juveniles, subadults, and females, in addition to males. Most recaptures occurred in the original or adjacent capture/release zone, regardless of tagging or tracking year and duration (Sterling et al. 2013, our Table 2). Satellite telemetry of 1 female and 2 subadults showed similar patterns to the tracked males, with greatly enhanced resolution provided by Fastloc GPS technology for subadult 85946 (Fig. 3). Limited movements have also been reported for many satellite-tracked females and immature turtles at foraging grounds around the world (Godley et al. 2003, Troëng et al. 2005, Broderick et al. 2007, McClellan \& Read 2009, Hart \& Fujisaki 2010, Shimada et al. 2016). At Palmyra, how- 
ever, home range and core-use areas were smaller and less varied than those of most immature turtles or females tracked along more extensive coastlines. High-use areas were mostly concentrated within the capture/release or adjacent zone and were substantially smaller than the estimated $155 \mathrm{~km}^{2}$ of available lagoon and reef habitat. Displacement at Palmyra was further limited by an apparent lack of seasonal migrations. Low temperature variation in the region (Hijmans et al. 2005) likely greatly reduces the need for seasonal movement, which also carries energetic costs for capital breeders (Jonsson 1997).

\section{Departures from Palmyra}

Palmyra male green turtles displayed extended residency and sparse evidence of movements beyond the atoll. Two of the 3 known departures revealed previously unknown connectivity with the nearby Northern Line Islands, in the Kiribati rookery group (Balazs 1981, Maison et al. 2010). The flipper tag return came from a female, and Palmyra's females are believed to depart for breeding as there is very little nesting on Palmyra (Sterling et al. 2013). Indeed, the natal origins of Palmyra's green turtles were genetically traced to rookeries in the SouthCentral and West-Central Pacific Regional Management Units (Naro-Maciel et al. 2014). The genetic findings are supported by the second flipper tag return in Kosrae of a turtle identified as a subadult when tagged 8 yr earlier on Palmyra. Although rookery coverage in the genetic study was comprehensive, no genetic samples from Kiribati were available. There may be additional, uncharacterized source rookeries in the Phoenix Islands, Kiribati, with nesting grounds reported on Canton (Kanton) and Enderbury Islands (Balazs 1975, Maison et al. 2010). The remote Central Pacific remains a poorly studied region for marine turtles (Balazs 1981, Craig et al. 2004, Godley et al. 2008). Thus, additional regionwide mark-recapture, satellite, and genetic data are needed to better discern the migratory behavior of all Palmyra turtles.

Contrary to green turtles elsewhere, Palmyra's male turtles, like those of Cyprus (Wright et al. 2012), showed no evidence of annual migration and underscore the persistent knowledge gap surrounding this marine chelonian sex (Limpus 1993, Hays et al. 2010, Balazs et al. 2015). Male 85920 provided a tantalizing glimmer of information through the rarely documented, near-circular pelagic track, also observed in a hawksbill in the Phoenix Islands
(Jayne \& Solomona 2007). Circular loops among post-nesting green turtles in Costa Rica were attributed to Sargassum foraging (Troëng et al. 2005). Those females made counterclockwise movements matching surface currents, and 85920 moved clockwise also with an apparent relationship to ocean currents. The normal behavior for post-pelagic green turtles was thought to be neritic feeding, but other studies have begun to document post-recruitment pelagic foraging or movements (Hatase et al. 2006, Parker et al. 2015, Williard et al. 2017). This track also coincided with the regional peak nesting season of October-November (Balazs 1981, Maison et al. 2010), and approached Northern Line Islands rookeries (Fig. 4). Even so, the telemetry data do not reveal male reproductive behavior such as remaining in a courtship area for about 2 mo. On the other hand, the track could indicate a mate search, possibly reflecting an Allee effect; the small population size and wide dispersion of females nesting all year across Kiribati's Islands could affect the success of mating encounters. Therefore, neither explanation for this loop - foraging versus breeding migrations - could be dismissed.

Another hypothesis proposed for future testing is that mating occurs at Palmyra and that most breeding migrations are undertaken by females inseminated at the refuge, as reported in Australia (Limpus 1993), saving males the energetic costs of migration (Arendt et al. 2012). Mating activity has not been frequently recorded at Palmyra, but during fieldwork within the refuge's boundaries (Fig. 1), several males were observed with extruding reproductive organs, possibly indicating sexual activity, and behavior consistent with mating was photographed. The lack of continuous monitoring paired with the temporal and spatial dispersion of mating turtles could hinder observation of this behavior at the remote site.

\section{Management recommendations}

This study demonstrates the importance of highquality MPAs such as Palmyra for regional conservation including migratory species, and our main recommendation is to keep this reserve well-protected. The high site fidelity to foraging grounds of hardshelled marine turtles in general means that they will continue to return to and use protected areas, underscoring the fundamental importance of these areas for marine conservation. As shown in this study, and supported by a global analysis, reserves that are large and well-established are widely used by green 
turtles (Scott et al. 2012). Providing optimal and highly protected habitat that spatially encompasses most focal organisms' movements, as achieved at Palmyra, is key to protected area effectiveness (McClellan \& Read 2009, Scott et al. 2012, Shimada et al. 2016). Such permanent areas may be particularly important in achieving conservation goals and improving the metrics of marine reserves recognized to be effective (Simard et al. 2016).

In the most successful marine protected areas, protection measures closely match the needs of key organisms, including marine turtles (Scott et al. 2012, Shimada et al. 2016). The present study highlights an unusual situation in which areas heavily used by migratory organisms were completely contained within refuge boundaries. Marine turtles and other migratory megafauna may depart reserve boundaries and thus gain only partially from protection, due to limited spatial overlap or insufficient conservation levels (McClellan \& Read 2009, Scott et al. 2012, Shimada et al. 2016). The extended residency patterns revealed herein confirm that Palmyra stands out among protected areas, as it sustains and effectively shields endangered green turtles that spend most of their lives within its borders. The high-quality habitat shelters large juvenile, subadult, and adult turtles, the stages known to most impact population growth (Crouse et al. 1987).

The Palmyra green turtle population is genetically distinct from others in the region (Naro-Maciel et al. 2014) and forages in a unique and relatively undisturbed habitat (McFadden et al. 2010, 2014, Sterling et al. 2013). Healthy marine turtles play important roles in the ecosystem, for example through nutrient transport and predator-prey interactions (Bjorndal \& Jackson 2003). With highly migratory megafauna, these ecosystem services often extend across different nations and these ties can foster or require international cooperation for research and conservation initiatives. Indeed, threat levels and legislative measures in the Central Pacific vary widely (Maison et al. 2010, Sterling et al. 2013). The main recommendation of this study is, therefore, to maintain or expand the protective measures at Palmyra and other protected areas including the Pacific Remote Islands Marine National Monument, within which it is contained.

Acknowledgements. We sincerely thank our anonymous reviewers and Editor for helpful comments that strengthened the manuscript. Jimmy Breeden, Renee Breeden, Nina Chen, Arjun Clarry, Peter Ersts, Arielle Farkas, Pamela Farkas, Kevin Frey, Alexander Gaos, Andrés Gómez, Kristen
Hart, Cheryl King, Jennifer Lynch, Kim Maison, Frannie Nilsen, Amanda Pollock, Kydd Pollock, Marc Rice (Hawai'i Preparatory Academy), Thomas Selby, Jennifer VanderVeur, and Thierry Work are sincerely thanked for their invaluable assistance in the field. Denise Parker provided helpful initial analysis. Debbie Stakem at Argos-CLS and Natalie Crandall at Wildlife Computers are thanked for their assistance with data. We acknowledge the Palmyra Atoll National Wildlife Refuge, US Fish and Wildlife Service, Department of the Interior, The Nature Conservancy, and the Palmyra Atoll Research Consortium. This is Palmyra Atoll Research Consortium paper number 144. The project was carried out with IACUC approval under NOAA permit 10027. This work was funded by the National Oceanic and Atmospheric Administration's (NOAA) National Marine Fisheries Service, US Department of Commerce (grant numbers NA07NMF4540185, NA10NMF4540299). The statements, findings, conclusions, and recommendations are those of the authors and do not necessarily reflect the views of NOAA or the US Department of Commerce. Additional support for this project was provided by Ms. Pamela Farkas, Royal Caribbean Ocean Fund, and the Regina Bauer Frankenberg Foundation for Animal Welfare. We dedicate this paper to the memory of Katherine W. McFadden, a committed conservation scientist, team member, and dear friend.

\section{LITERATURE CITED}

Ackerman RA (1997) The nest environment and the embryonic development of sea turtles. In: Lutz PL, Musick JA (eds) The biology of sea turtles, Vol I. CRC Press, Boca Raton, FL, p 83-106

Arendt MD, Segars AL, Byrd JI, Boynton J and others (2012) Distributional patterns of adult male loggerhead sea turtles (Caretta caretta) in the vicinity of Cape Canaveral, Florida, USA during and after a major annual breeding aggregation. Mar Biol 159:101-112

Balazs GH (1975) Marine turtles in the Phoenix Islands. Atoll Res Bull 184:1-7

Balazs GH (1981) Status of sea turtles in the Central Pacific Ocean. In: Bjorndal KA (ed) Biology and conservation of sea turtles. Smithsonian Institution Press, Washington, DC

*Balazs GH, Van Houtan KS, Hargrove SA, Brunson SM, Murakawa SKK (2015) A review of the demographic features of Hawaiian green turtles (Chelonia mydas). Chelonian Conserv Biol 14:119-129

Balazs GH, Parker DM, Rice MR (2017) Ocean pathways and residential foraging locations for satellite tracked green turtles breeding at French Frigate Shoals in the Hawaiian Islands. Micronesica 2017-04:1-19

* Barnett A, Abrantes KG, Seymour J, Fitzpatrick R (2012) Residency and spatial use by reef sharks of an isolated seamount and its implications for conservation. PLOS ONE 7:e36574

* Baudouin M, de Thoisy B, Chambault P, Berzins R and others (2015) Identification of key marine areas for conservation based on satellite tracking of post-nesting migrating green turtles (Chelonia mydas). Biol Conserv 184: 36-41

Bjorndal KA, Jackson JB (2003) Roles of sea turtles in marine ecosystems: reconstructing the past. In: Lutz PL, Musick JA, Wyneken J (eds) The biology of sea turtles, Vol 2. 
CRC Press, Boca Raton, FL, p 259-274

Bowen BW, Karl SA (2007) Population genetics and phylogeography of sea turtles. Mol Ecol 16:4886-4907

Braun CL, Smith JE, Vroom PS (2008) Examination of algal diversity and benthic community structure at Palmyra Atoll, US Line Islands. Proc $11^{\text {th }}$ Int Coral Reef Symp: 865-869

*Boderick AC, Coyne MS, Fuller WJ, Glen F, Godley BJ (2007) Fidelity and over-wintering of sea turtles. Proc R Soc B 274:1533-1538

Burt WH (1943) Territoriality and home range concepts as applied to mammals. J Mammal 24:346-352

* Calenge C (2006) The package adehabitat for the R software: a tool for the analysis of space and habitat use by animals. Ecol Modell 197:516-519

Chan SKF, Chan JK, Lo LT, Balazs GH (2003) Satellite tracking of the post-nesting migration of a green turtle (Chelonia mydas) from Hong Kong. Mar Turtle Newsl 102:2-4

* Cheng IJ (2000) Post-nesting migrations of green turtles (Chelonia mydas) at Wan-An Island, Penghu Archipelago, Taiwan. Mar Biol 137:747-754

* Collen JD, Garton DW, Gardner JPA (2009) Shoreline changes and sediment redistribution at Palmyra Atoll (Equatorial Pacific Ocean): 1874-present. J Coast Res 253:711-722

Coyne MS, Godley BJ (2005) Satellite Tracking and Analysis Tool (STAT): an integrated system for archiving, analyzing and mapping animal tracking data. Mar Ecol Prog Ser 301:1-7

Craig P, Parker D, Brainard R, Rice M, Balazs GH (2004) Migrations of green turtles in the central South Pacific. Biol Conserv 116:433-438

* Crouse DT, Crowder LB, Caswell H, Oct N, Crouse T (1987) A stage-based population model for loggerhead sea turtles and implications for conservation. Ecology 68: 1412-1423

* Doherty PD, Baxter JM, Godley BJ, Graham RT and others (2017) Testing the boundaries: seasonal residency and inter-annual site fidelity of basking sharks in a proposed marine protected area. Biol Conserv 209:68-75

Dujon AM, Lindstrom RT, Hays GC (2014) The accuracy of Fastloc-GPS locations and implications for animal tracking. Methods Ecol Evol 5:1162-1169

Fieberg J, Kochanny CO (2005) Quantifying home-range overlap: the importance of the utilization distribution. J Wildl Manag 69:1346-1359

Fukuoka T, Narazaki T, Sato K (2015) Summer-restricted migration of green turtles Chelonia mydas to a temperate habitat of the northwest Pacific Ocean. Endang Species Res 28:1-10

* Gitzen RA, Millspaugh JJ, Kernohan BJ (2006) Bandwidth selection for fixed-kernel analysis of animal utilization distributions. J Wildl Manag 70:1334-1344

Godley B, Lima E, Åkesson S, Broderick A and others (2003) Movement patterns of green turtles in Brazilian coastal waters described by satellite tracking and flipper tagging. Mar Ecol Prog Ser 253:279-288

Godley BJ, Blumenthal JM, Broderick AC, Coyne MS, Godfrey MH, Hawkes LA, Witt MJ (2008) Satellite tracking of sea turtles: Where have we been and where do we go next? Endang Species Res 4:3-22

*González Carman V, Falabella V, Maxwell S, Albareda D, Campagna C, Mianzan H (2012) Revisiting the ontogenetic shift paradigm: the case of juvenile green turtles in the SW Atlantic. J Exp Mar Biol Ecol 429:64-72
Griffen BD, Drake JM (2008) Effects of habitat quality and size on extinction in experimental populations. Proc R Soc B 275:2251-2256

Hamann M, Limpus CW, Owens DW (2003) Reproductive cycles of males and females. In: Lutz PL, Musick JA, Wyneken J (eds) The biology of sea turtles, Vol 2. CRC Press, Boca Raton, FL, p 135-162

Hamann M, Godfrey MH, Seminoff JA, Arthur KE and others (2010) Global research priorities for sea turtles: informing management and conservation in the 21st century. Endang Species Res 11:245-269

Hargrove S, Work TM, Brunson S, Foley AM, Balazs G (2016) Proceedings of the 2015 international summit on fibropapillomatosis: global status, trends, and population impacts. NOAA Tech Memo NMFS-PIFSC-54. US Department of Commerce, Honolulu, HI

*Hart K, Fujisaki I (2010) Satellite tracking reveals habitat use by juvenile green sea turtles Chelonia mydas in the Everglades, Florida, USA. Endang Species Res 11: 221-232

Hart KM, Zawada DG, Fujisaki I, Lidz BH (2013) Habitat use of breeding green turtles Chelonia mydas tagged in Dry Tortugas National Park: making use of local and regional MPAs. Biol Conserv 161:142-154

* Hatase H, Sato K, Yamaguchi M, Takahashi K, Tsukamoto $\mathrm{K}$ (2006) Individual variation in feeding habitat use by adult female green sea turtles (Chelonia mydas): Are they obligately neritic herbivores? Oecologia 149: $52-64$

*Hays GC, Broderick AC, Glen F, Godley BJ, Nichols WJ (2001) The movements and submergence behaviour of male green turtles at Ascension Island. Mar Biol 139: 395-399

Hays GC, Fossette S, Katselidis KA, Schofield G, Gravenor MB (2010) Breeding periodicity for male sea turtles, operational sex ratios, and implications in the face of climate change. Conserv Biol 24:1636-1643

*Hazel J (2009) Evaluation of fast-acquisition GPS in stationary tests and fine-scale tracking of green turtles. J Exp Mar Biol Ecol 374:58-68

*Hijmans RJ, Cameron SE, Parra JL, Jones PG, Jarvis A (2005) Very high resolution interpolated climate surfaces for global land areas. Int J Climatol 25:1965-1978

Hoenner X, Whiting SD, Hindell MA, McMahon CR (2012) Enhancing the use of Argos satellite data for home range and long distance migration studies of marine animals. PLOS ONE 7:e40713

James MC, Eckert SA, Myers RA (2005) Migratory and reproductive movements of male leatherback turtles (Dermochelys coriacea). Mar Biol 147:845-853

Jayne K, Solomona P (2007) Lady Vini's big Pacific adventure. Western Pacific Regional Fishery Managment Council, Apia

Jonsson KI (1997) Capital and income breeding as alternative tactics of resource use in reproduction. Oikos 78: 57-66

Karczmarski L, Würsig B, Gailey G, Larson KW, Vanderlip C (2005) Spinner dolphins in a remote Hawaiian atoll: social grouping and population structure. Behav Ecol 16: 675-685

Limpus CJ (1993) The green turtle, Chelonia mydas, in Queensland: breeding males in the southern Great Barrier Reef. Wildl Res 20:513-523

KLimpus CJ, Miller JD, Parmenter CJ, Reimer D, McLachlan N, Webb R (1992) Migration of green (Chelonia mydas) 
and loggerhead (Caretta caretta) turtles to and from eastern Australian rookeries. Wildl Res 19:347-358

Lyons AJ, Turner WC, Getz WM (2013) Home range plus: a space-time characterization of movement over real landscapes. Mov Ecol 1:2

Maison KA, Kelly IK, Frutchey KP (2010) Green turtle nesting sites and sea turtle legislation throughout Oceania. US Department of Commerce, Honolulu, HI

McClellan C, Read A (2009) Confronting the gauntlet: understanding incidental capture of green turtles through fine-scale movement studies. Endang Species Res 10:165-179

McFadden KW, Sterling EJ, Holmes KE, Naro-Maciel E (2010) Structure of nearshore algal communities and their relationship with green sea turtle feeding habits at a foraging ground In the Central Pacific. In: Proc 30th Annu Symp Sea Turtle Biology and Conservation, 24-30 April 2010, Goa. NOAA Tech Memo NMFS-SEFSC-640, p 98-99 (Abstract)

McFadden KW, Gómez A, Sterling EJ, Naro-Maciel E (2014) Potential impacts of historical disturbance on green turtle health in the unique \& protected marine ecosystem of Palmyra Atoll (Central Pacific). Mar Pollut Bull 89: 160-167

MCI (Marine Conservation Institute) (2018) Atlas of marine protection. www.mpatlas.org/ (accessed 10 July 2018)

* Meylan AB, Bowen BW, Avise JC (1990) A genetic test of the natal homing versus social facilitation models for green turtle migration. Science 248:724-727

Musick J, Limpus C (1997) Habitat utilization and migration in juvenile sea turtles. In: Lutz P, Musick JA (eds) The biology of sea turtles, Vol I. CRC Press, Boca Raton, FL, p 137-165

Naro-Maciel E, Gaughran SJ, Putman NF, Amato G and others (2014) Predicting connectivity of green turtles at Palmyra Atoll, central Pacific: a focus on mtDNA and dispersal modelling. J R Soc Interface 11:20130888

Nurzia Humburg I, Balazs GH (2014) Forty years of research: recovery records of green turtles observed or originally tagged at French Frigate Shoals in the Northwestern Hawaiian Islands, 1973-2013. NOAA Tech Memo NMFS-PIFSC-40. US Department of Commerce, Honolulu, HI

Papastamatiou YP, Friedlander AM, Caselle JE, Lowe CG (2010) Long-term movement patterns and trophic ecology of blacktip reef sharks (Carcharhinus melanopterus) at Palmyra Atoll. J Exp Mar Biol Ecol 386:94-102

Papastamatiou Y, DeSalles P, McCauley D (2012) Arearestricted searching by manta rays and their response to spatial scale in lagoon habitats. Mar Ecol Prog Ser 456: 233-244

Parker DM, Balazs GH, Frutchey K, Kabua E, Langidrik M, Boktok K (2015) Conservation considerations revealed by the movements of post-nesting green turtles from the Republic of the Marshall Islands. Micronesica 2015-03: $1-9$

Plotkin P (2003) Adult migrations and habitat use. In: Lutz PL, Musick JA, Wyneken J (eds) The biology of sea turtles, Vol 2. CRC Press, Boca Raton, FL, p 225-241

Plotkin PT, Owens DW, Byles RA, Patterson R (1996) Departure of male olive ridley turtles (Lepidochelys olivacea) from a nearshore breeding ground. Herpetologica 52:1-7

QGIS (2016) QGIS geographic information system. https:// www.qgis.org/en/site/ (accessed 10 July 2018)

R Core Team (2016) R: a language and environment for sta- tistical computing. R Foundation for Statistical Computing, Vienna

Kees A, Alfaro-Shigueto J, Barata P, Bjorndal K and others (2016) Are we working towards global research priorities for management and conservation of sea turtles? Endang Species Res 31:337-382

* Russell DJ, Hargrove S, Balazs GH (2011) Marine sponges, other animal food, and nonfood items found in digestive tracts of the herbivorous marine turtle Chelonia mydas in Hawai'i. Pac Sci 65:375-381

* Sandin SA, Smith JE, DeMartini EE, Dinsdale EA and others (2008) Baselines and degradation of coral reefs in the Northern Line Islands. PLOS ONE 3:e1548

Scott R, Hodgson DJ, Witt MJ, Coyne MS and others (2012) Global analysis of satellite tracking data shows that adult green turtles are significantly aggregated in Marine Protected Areas. Glob Ecol Biogeogr 21:1053-1061

Seminoff JA (2004) Chelonia mydas. The IUCN Red List of Threatened Species. 2004:e.T4615A11037468. www.iucn redlist.org/details/4615/0 (accessed 10 July 2018)

Seminoff JA, Zárate P, Coyne M, Foley DG, Parker D, Lyon BN, Dutton PH (2008) Post-nesting migrations of Galápagos green turtles Chelonia mydas in relation to oceanographic conditions: integrating satellite telemetry with remotely sensed ocean data. Endang Species Res 4: 57-72

Shaver DJ, Schroeder BA, Byles RA, Burchfield PM, Peña JP, Márquez R, Martinez HJ (2005) Movements and home ranges of adult male Kemp's ridley sea turtles (Lepidochelys kempii) in the Gulf of Mexico investigated by satellite telemetry. Chelonian Conserv Biol 4:817-827

* Shimada T, Jones R, Limpus C, Groom R, Hamann M (2016) Long-term and seasonal patterns of sea turtle home ranges in warm coastal foraging habitats: implications for conservation. Mar Ecol Prog Ser 562:163-179

* Shimada T, Limpus C, Jones R, Hamann M (2017) Aligning habitat use with management zoning to reduce vessel strike of sea turtles. Ocean Coast Manage 142:163-172

Simard F, Laffoley D, Baxter JM (eds) (2016) Marine protected areas and climate change: adaptation and mitigation synergies, opportunities and challenges. IUCN, Gland

Smith JE, Brainard R, Carter A, Dugas S and others (2016) Re-evaluating the health of coral reef communities: baselines and evidence for human impacts across the central Pacific. Proc R Soc B 283:20151985

* Sterling EJ, McFadden KW, Holmes KE, Vintinner EC, Arengo F, Naro-Maciel E (2013) Ecology and conservation of marine turtles in a Central Pacific foraging ground. Chelonian Conserv Biol 12:2-16

Trevor AP (2010) Turtle research and monitoring database system (TREDS): annual report 2009. Secretariat of the Pacific Regional Environment Program, Apia

Troëng S, Evans DR, Harrison E, Lagueux CJ (2005) Migration of green turtles Chelonia mydas from Tortuguero, Costa Rica. Mar Biol 148:435-447

Van Dam R, Diez C, Balazs G, Colón Colón L, McMillan W, Schroeder B (2008) Sex-specific migration patterns of hawksbill turtles breeding at Mona Island, Puerto Rico. Endang Species Res 4:85-94

Whiting SD, Murray W, Macrae I, Thorn R, Chongkin M, Koch AU (2008) Non-migratory breeding by isolated green sea turtles (Chelonia mydas) in the Indian Ocean: biological and conservation implications. Naturwissenschaften 95:355-360 
Wibbels T, Owens DW, Limpus CJ, Reed PC, Amoss MS (1990) Seasonal changes in serum gonadal steroids associated with migration, mating, and nesting in the loggerhead sea turtle (Caretta caretta). Gen Comp Endocrinol 79:154-164

Williams GJ, Smith JE, Conklin EJ, Gove JM, Sala E, Sandin SA (2013) Benthic communities at two remote Pacific coral reefs: effects of reef habitat, depth, and wave energy gradients on spatial patterns. PeerJ 1:e81

Williard AS, Hall AG, Fujisaki I, McNeill JB (2017) Oceanic

Editorial responsibility: Paolo Casale,

Pisa, Italy overwintering in juvenile green turtles Chelonia mydas from a temperate latitude foraging ground. Mar Ecol Prog Ser 564:235-240

* Winker K, Rappole JH, Ramos MA (1995) The use of movement data as an assay of habitat quality. Oecologia 101: 211-216

* Wright LI, Fuller WJ, Godley BJ, McGowan A, Tregenza T, Broderick AC (2012) Reconstruction of paternal genotypes over multiple breeding seasons reveals male green turtles do not breed annually. Mol Ecol 21:3625-3635

Submitted: April 5, 2018; Accepted: August 17, 2018

Proofs received from author(s): October 4, 2018 